\title{
Intercultural Education in Schools: From Policies to Practices in Catalonia (Spain)*
}

[Artículos de investigación]

\author{
Mònica Macià Bordalba ${ }^{* *}$ \\ Àngels Torrelles Montanuy ${ }^{* * * *}$
}

Recibido: 12 de noviembre de 2020

Aceptado: 03 de marzo de 2021

Citar como:

Macia, M. y Torrelles, À. (2021). Intercultural Education in Schools: From Policies to Practices in Catalonia (Spain). Campos en Ciencias Sociales, 9(1). https://doi.org/10.15332/25006681.6924

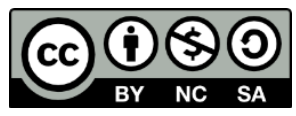

\begin{abstract}
Intercultural education is considered to be the most appropriate pedagogical model to promote inclusion, coexistence, and social cohesion both in Catalonia and in other countries. However, its philosophy is often misunderstood at the political or practical level. In this regard, this article examines the connection between national policies and what really happens in schools in Catalonia (Spain), a pioneering region in the reception of foreign students and, therefore, also a pioneer in the inclusion of intercultural discourse. Specifically, we first examine the Catalonian
\end{abstract}

\footnotetext{
* This article is the result of the research Project "Diversidad cultural e igualdad de oportunidades en la escuela", developed by the grase group: http://www.grase.udl.cat/

** University of Lleida. E-mail: monica.macia@geosoc.udl.cat; ORCID: https://orcid.org/0000-0002-4841-737X

*** ORCID: https://orcid.org/0000-0001-7347-4571
} 
policies aimed at managing cultural diversity and intercultural education that have been developed since the 2000s up until today. Secondly, we present the results of a quantitative study carried out in 545 primary schools in Catalonia, in order to acknowledge the practices implemented in schools to prepare students for living in our increasingly diverse society, as well as their needs and requirements to better achieve such a commitment. Results show that whilst schools are implementing actions aimed at both fostering the integration of culturally diverse pupils as well as enhancing the intercultural competence of all students, there are still some gaps at the political level that prevent schools from developing a holistic intercultural education.

Keywords: cultural diversity, intercultural education, intercultural competence, pedagogical practices, policies.

\section{Educación intercultural en las escuelas: de las políticas a las prácticas en Cataluña (España)}

\section{Resumen}

La educación intercultural se considera el modelo pedagógico más adecuado para favorecer la inclusión, la convivencia y la cohesión social tanto en Cataluña como en otros países. Sin embargo, su filosofía a menudo se malinterpreta a nivel político o práctico. En este sentido, este artículo examina la conexión entre las políticas nacionales y lo que realmente sucede en las escuelas de Cataluña (España), una región pionera en la recepción de estudiantes extranjeros y, por tanto, también pionera en la inclusión del discurso intercultural. En concreto, examinamos en primer lugar las políticas catalanas orientadas a la gestión de la diversidad cultural y la educación intercultural que se han desarrollado desde la década del 2000 hasta la actualidad. En segundo lugar, presentamos los resultados de un estudio cuantitativo realizado en 545 centros de educación primaria de Cataluña, con el fin de reconocer las prácticas implementadas en los centros educativos para preparar a los estudiantes para vivir en nuestra sociedad cada vez más diversa, así como necesidades y requisitos para 
lograr este compromiso. Los resultados muestran que, si bien las escuelas están implementando acciones dirigidas tanto a fomentar la integración de alumnos culturalmente diversos como a mejorar la competencia intercultural de todos los estudiantes, todavía existen algunas brechas a nivel político que impiden que las escuelas desarrollen una educación intercultural holística.

Palabras clave: diversidad cultural, educación intercultural, competencia intercultural, prácticas pedagógicas, políticas.

\section{Introduction}

In recent decades, many countries have undergone different stages in the management of cultural diversity, going from assimilationist programs and policies (monocultural perspective) to more multicultural and intercultural approaches. Spain, and the Spanish educational system, like those of other societies, has undergone this same evolution (García \& Goenechea, 2009). Initially, those who were culturally different (especially the Roma) were excluded from schools just as they were from other institutional and social spheres. This was followed by a shift from exclusion to segregation with the so-called 'bridge schools', which became a form of non-transitory segregated schooling (Santos Rego, Crespo, Lorenzo \& Godás, 2012). With the arrival of democracy, integrationist models also came to Spain. These models sought to incorporate the culturally different into ordinary classrooms with the support of compensatory educational programs intended to benefit the geographical areas or populations that, due to their specific characteristicssocioeconomic, cultural, etc.-required special educational attention. Integrationist models continued until the mid-1990s, at which point compensatory programs began to be combined with certain intercultural references and practices (Márquez \& García, 2014). Today, the intercultural model is considered to be the most appropriate pedagogical response for inclusion, coexistence, and social cohesion (Catalan Ministry of Education, 
2018), as in many European and international contexts (Bouchard, 2011). But what is understood by intercultural education?

A defining trait of intercultural education is its quest for social justice, equality, and human rights (Banks, 2009; Whitaker, 2015); another one is its pluralist mindset (Bouchard, 2011; Neuer, 2012), understood as sensitivity to ethnocultural diversity and the rejection of all discrimination based on difference. It means that intercultural education embraces two different streams of action. On the one hand, it helps and provides support to pupils with a migration background to find their way in school and society to address the problem of educational inequality around the globe. On the other hand, it shapes attitudes of equality and respect for culturally diverse people in all students in order to foster coexistence and social cohesion (Allemann-Gionda, 2008). Thus, besides special measures to integrate migrant pupils, intercultural education must allow all students to develop the intercultural competence so necessary in the culturally diverse world in which we are living (Council of Europe, 2014). In this regard, a definition of intercultural competence from the instrumental-rational perspective can be found in Deardorff (2006a), who defines the concept as the ability to interact effectively and appropriately in multicultural situations, based on specific attitudes, intercultural knowledge, and skills. In fact, many European institutions (Council of Europe, 2014; UNESCO, 2013) also presented a conceptual framework for the concept of intercultural competence as a combination of attitudes, knowledge, and skills. To sum up, the role of education in the integration of migrant students, as well as the improvement of social cohesion by developing intercultural competence in all students, seems to be accepted and recognized around the globe (UNESCO, 2013; OECD, 2012). It means that intercultural education is aimed at all students, even in monocultural contexts or seemingly homogeneous groups (Lourenço, 2018; Mikander, Zilliacus \& Holm, 2018). 
However, European countries have great autonomy in the field of education, with the consequent diversification of policies and practices (Gundara \& Portera, 2008). In this regard, Spain has a decentralized system where the nineteen autonomous communities have great autonomy in the field of education, which argues why, within the country, there are different views regarding the understanding of intercultural education (Garreta, 2014). Further, Tarocci (2012) stresses two significant gaps in the field of intercultural education. Firstly, there is a gap between the official philosophy of intercultural education and the policies put in place.

Secondly, there is often a gap between official education policies on the one hand and practice on the other (Allemann-Gionda, 2008).

In light of these gaps, this paper will analyze the policies and practices of intercultural education in Catalonia (Spain), a pioneering region in the reception of foreign students and, therefore, also a pioneer in the inclusion of intercultural discourse. Specifically, this study maps out and dissects the connection between national policies and what happens in schools, with the ultimate goal of suggesting a number of guidelines and recommendations to reach a truly intercultural education in schools that is, today, still far from being achieved (Leiva, 2017).

To do this, we will conduct a two-level analysis: first, at the political level, by analyzing national policies put in place as well as other national recommendations regarding intercultural education; and secondly, at the school level, by presenting the results of quantitative research focused on knowing which practices and activities schools are carrying out under the name of "intercultural education." 


\section{Methodology}

\section{Objectives}

Intending to improve scientific knowledge on how educational systems manage an increasingly multicultural society, we conducted a study on intercultural education in primary schools (6-12 years) in the region of Catalonia (Spain). The specific goals of the study were the following:

- To analyze national policies regarding intercultural education from the 1990 s to the present day.

- To analyze actions that schools carry out within the conceptual framework of intercultural education.

- To detect the deficiencies and needs of our educational system in the field of intercultural education.

\section{Instrument}

To achieve the first goal, we analyzed the evolution of national policies regarding intercultural education by assembling, summarizing, and integrating the main discourses of the Catalan Ministry of Education and other official documents and national regulations. To achieve the second and third objectives, we conducted a quantitative study using telephone surveys.

\section{Participants}

Participants were members of the schools' management teams with some years of experience at the same school. The sample was of 545 primary schools (students aged between 6 and 12 years old), which, assuming the worst-case scenario of $\mathrm{p}=\mathrm{q}=50 \%$, and with a confidence level of $95.5 \%$, had a margin of error of $\pm 3.5 \%$. The selection of schools was performed based on the list of schools in Catalonia and with a table of random numbers. Thus, 
the schools were selected at random, albeit ensuring that the sample represented the regional distribution of populations.

\section{Procedure}

To achieve the first goal, we collected and selected data from normative and discursive documents of the Ministry of Education of Catalonia. Specifically, we analyzed educational legislation, guidance, and consultation documents from the administration published on their institutional website, as well as scientific publications related to the subject.

On the other hand, the questionnaire was carried out from November 2016 to February 2017. On completion of the empirical work, the questionnaires were coded and tabulated, since all the questions presented in this article were open-ended questions, to make it possible to obtain broader and more detailed information (López-Roldán \& Fachelli, 2015). After this, a descriptive analysis of the data was performed based on the response percentages obtained from the total number of respondents. In this analysis, we took the percentage of immigration at schools as the independent variable since the literature suggests that intercultural education is often influenced by school demographics, with more practices related to it at schools with higher percentages of migrant pupils (Forrest, Lean, \& Dunn, 2016; Palaiologou \& Faas, 2012). Therefore, schools were grouped into categories based on the level of immigration. The classification of schools was the following: schools that had less than $5 \%$ of migrant students (32.7\%), schools in which migrant students accounted for $6 \%$ to $20 \%$ of students (36.5\%), schools in which migrant students accounted for $21 \%$ to $50 \%$ of students (20.9\%), and, finally, schools in which students of foreign origin accounted for more than $50 \%$ of the total student body (9.9\%). Finally, the fourth goal was achieved by interpreting the results from both phases. 


\section{Results and Discussion}

\section{Policies in Catalonia: from the beginning of intercultural discourse to the present day}

In the 1990s, Catalonia began to implement a global policy of immigration, which was consolidated in 2000 with the creation of the Secretariat for Immigration. Many political actions were carried out after this. Therefore, in these years, the discourse of the Catalan government took an intercultural turn, and the first international discourses and practices emerged, although they coexisted with compensatory programs that strived solely to promote the integration of newly-arrived foreign students.

In this context, in 1996, the Catalan Ministry of Education published the document named Eix transversal sobre educació intercultural (CrossCutting Line on Intercultural Education), considered to be the first strong commitment to interculturalism in the field of education. This document stated that intercultural education must not be a superficial educational practice, outside the ordinary curriculum, nor should it be targeted solely at migrant students, but rather at all students in all schools. Thus, this document was aligned with the philosophy of the intercultural model, which states that intercultural education must be aimed at all students, not just minorities and/or immigrants (Lourenço, 2018; Mikander, Zilliacus \& Holm, 2018), that education should be concerned with developing intercultural competence (Council of Europe, 2014; Deardorff, 2006a), and that intercultural education cannot be seen as an add-on to the curriculum in occasional projects (Neuer, 2012).

These policies and discourses, however, must be contextualized in a time marked by the start of the influx of foreign migrants of multiple origins, and consequently, by the arrival of a large number of students at different points throughout the academic year and with different levels of schooling. 
Of course, this influx and its impact were not the same in all schools. On the contrary, it was much greater in some schools than others as a result of how school places are assigned based on existing vacancies and the influence of the neighborhood of residence (Garreta, 2003).

The 2001-2004 Interministerial Immigration Plan, developed by the Catalan Secretariat for Immigration in 2001, proposed learning programs for newcomer students. Similarly, the 2003-2006 Action Plan for Students of Foreign Nationality had the main goal of schooling and integrating all students, but especially those of other cultures and origins. In 2004, the Language and Social Cohesion Plan was approved, which was aimed at fostering social cohesion and Catalan language learning. This plan entailed the disappearance of the Compensatory Education Program (active in Catalonia since 1990) and was accompanied by other innovative measures, such as the creation of welcome classrooms, the holding of school adaptation programs. and the creation of the Language, Interculturality, and Cohesion Teams, which sought to foster intercultural education in schools. Within the Language and Social Cohesion Plan, the First Integral Plan for the Gypsy People 2005-2008 was also framed, which, as an educational intervention, highlighted intercultural mediation and learning communities. Further, it aimed to incorporate gypsy culture into the organization and the curriculum with an intercultural orientation.

One year later (in 2005), the 2005-2008 Citizenship and Immigration Plan was developed. It maintained the measures established by the Language and Social Cohesion Plan but also developed more welcome actions to attend migrant pupils, such as improving communication with published materials. Other actions of this plan were improving teacher training regarding the reception of newly arrived students, providing specific guidelines on curricular adaptation to diversity, and hiring intercultural mediators. In 2009, the former plan was revised, and the 2009-2012 
Citizenship and Migration Plan was implemented, which included financial assistance to schools for producing teaching materials related to newly-arrived students, homework support workshops (assisted study), the production and dissemination of educational materials for the management of diversity, and the promotion of specific training in diversity management and interculturality. Finally, in the same year (2009), a new figure was created, named gypsy school promoters, specifically designed to integrate and help gypsy people. This figure was created within the Second Integral Plan for the Gypsy People 2009-2013, which gave continuity to the First Plan of 2005, and which encouraged informative and advisory sessions in the educational community. In 2014, these actions continued with the Third Integral Plan for the Gypsy People 2014-2016, following the same educational line.

Going back in time, and within the framework of European and international guidelines, the Government of Catalonia launched a Plan for Reducing School Failure in Catalonia for 2012-2018. This plan highlighted the importance of intercultural education, but only included the approach of developing intercultural competence in all students within the actions of linguistic and literacy learning-with the support and advice, when needed, of the Language, Interculturality, and Cohesion Teams.

Lastly, and currently in force, the 2017-2020 Citizens and Migration Plan was approved, which takes interculturalism as the model for social cohesion and coexistence. Within this plan, the Ministry of Education has launched a number of educational programs that stress the following measures: improving the welcome of families with a migratory background, enhancing the academic success of migrant children, promoting good practices in the environment of the educational success of children from other cultures, and implementing a holistic intercultural program in the school. 
Finally, and specifically in relation to the attention of gypsy students, there is the Fourth Integral Plan for the Roma in Catalonia, 2017-2020, which continues to implement the measures of previous plans to increase the enrolment of gypsy students in early childhood education (from one to sixyear-olds), enhancing their academic success and extending the school promoter to many schools.

All the previous plans mentioned, with their corresponding theoretical focus, are accompanied at the level of educational regulations by Law 12/2009, of July 10, 2009, which places social cohesion and inclusive education as two fundamental principles of the Catalan educational system. The decree displayed by this law is Decree 150/2017 related to the educational care of students within the framework of an inclusive system, which establishes a framework of reference and gives continuity to the actions undertaken by the Department of Education. Finally, two recent rulings must be mentioned for an idea of the future direction that the Catalan Government is taking in the field of cultural diversity in schools. First, there is Ruling ENS/585/2017, of March 17, 2017, which establishes the creation and implementation in all schools of the "Project of coexistence." This project stresses specific actions to help schools in the development of intercultural education within the classroom, school, and environment, targeted at all students and all schools. Secondly, there is Ruling ENS/2754/2018, of November 20, 2018, whereby the "Languages and Cultures of Origin" program is created, which integrates the teaching of different cultures and languages into the school curriculum in order to promote educational actions for heightening the plurilingual and multicultural competence of all students, both in class time and in extra-curricular hours. These type of programs, which focus on the pupils' mother tongue, are necessary for schools since they facilitate pupils' 
knowledge but also and foremost, they encourage positive attitudes towards cultural and linguistic diversity (Martínez, Yanes \& Llevot, 2016).

\section{Between national policies and practices}

In the previous section, we reported on the evolution of the policy documents regarding cultural diversity and intercultural discourse. The discussion is now going to focus on the practices that schools are implementing to prepare students for living in our increasingly diverse society. ${ }^{1}$ First, we need to distinguish between two approaches, according to the theoretical framework: on the one hand, actions aimed merely at culturally diverse students and, on the other, actions designed to improve intercultural competence in all students. In both categories, the results indicate the existence of diversification of actions, that is, that schools are implementing many activities to foster the integration of migrant students, as well as many activities to enhance all students' intercultural competence. In addition to this qualitative description of actions, there is also an encouraging quantitative result: in both categories, we recorded similar percentages on the implementation of actions, which means that schools are carrying out an intercultural education aligned with this philosophy, including activities to heighten the integration of culturally diverse students in conjunction with actions addressed to all students to enhance cultural understanding, relations, and social cohesion. Nevertheless, deeper analysis is necessary to acknowledge whether, and to what extent, national policies are aligned with practices put in place, as well as to detect if the practices implemented in schools are enough to assert that Catalonia is conducting a truly intercultural education.

\footnotetext{
${ }^{1}$ The specific question was: Society is increasingly culturally diverse. What are you doing in your school to face this reality?
}

Campos en Ciencias Sociales

ISSN: 2339-3688 | e-ISSN: 2500-6681 | DOI: https://doi.org/10.15332/25394363

Vol. 9 N.० 1 | enero-junio de 2021 


\section{Actions aimed at culturally diverse students to foster their integration and inclusion}

Focusing on the actions aimed at culturally diverse students, the most common activities in schools are the following: integrating culturally diverse students into the classroom and school (10.1\%), providing a welcoming and equal treatment to diverse students (15.2\%), meeting the specific needs of students with diverse backgrounds (13.4\%), and implementing actions and activities with and for diverse families (14.3\%), such as adapting communication to them, increasing meetings with families, and organizing workshops and activities where they can participate (Table 1). In fact, these actions are underpinned by national policies. Furthermore, many projects and protocols of action regarding the integration and welcome of migrant students and their families have been developed not only by the Catalan government with general plans but also by the Ministry of Education of Spain. Nowadays, these policies are maintained and are part of broader projects and programs taking the inclusive approach of enhancing equity, equal opportunities, and respect for diversity, as suggested by the 2009 Catalan Law-and that came into effect with the Decree of 2017. To summarize, the results of the quantitative study are aligned with the regulatory framework developed in Catalonia since the beginning of the migratory phenomena.

Table 1. Actions carried out by schools to work with culturally diverse students

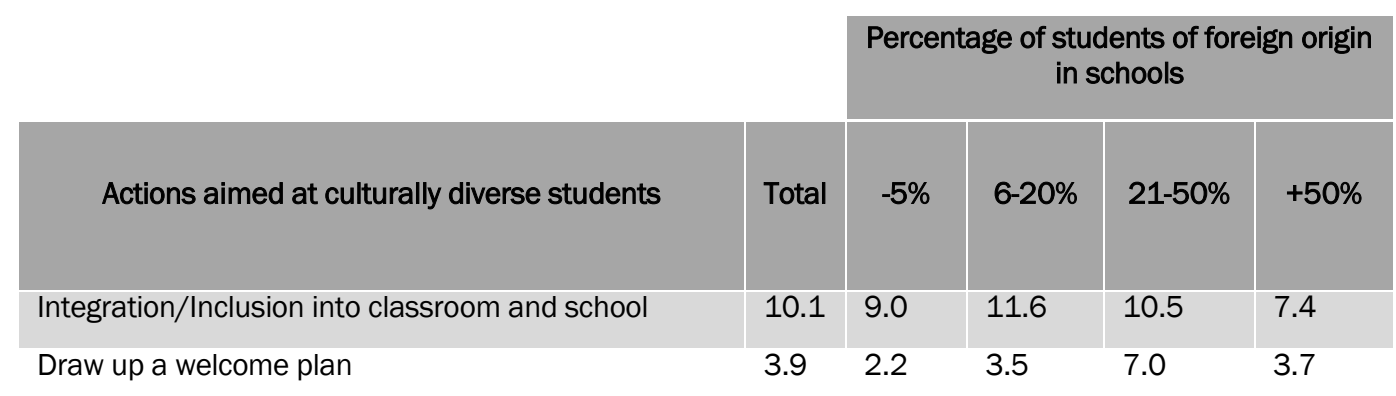

Campos en Ciencias Sociales

ISSN: 2339-3688 | e-ISSN: 2500-6681 | DOI: https://doi.org/10.15332/25394363

Vol. 9 N. ${ }^{\circ} 1$ | enero-junio de 2021 


\begin{tabular}{|c|c|c|c|c|c|}
\hline \multirow[b]{2}{*}{ Actions aimed at culturally diverse students } & \multirow[b]{2}{*}{ Total } & \multicolumn{4}{|c|}{$\begin{array}{l}\text { Percentage of students of foreign origin } \\
\text { in schools }\end{array}$} \\
\hline & & $-5 \%$ & $6-20 \%$ & $21-50 \%$ & $+50 \%$ \\
\hline $\begin{array}{l}\text { Provide a welcome and equal treatment to diverse } \\
\text { students }\end{array}$ & 15.2 & 16.9 & 13.5 & 15.8 & 14.8 \\
\hline $\begin{array}{l}\text { Implement different actions to adapt how the school } \\
\text { functions to diversity (in general) }\end{array}$ & 5.5 & 4.5 & 6.0 & 3.5 & 11.1 \\
\hline Treat diversity as something natural & 7.0 & 5.6 & 6.5 & 7.9 & 11.1 \\
\hline $\begin{array}{l}\text { Meet the specific needs of students with diverse } \\
\text { backgrounds }\end{array}$ & 13.4 & 8.5 & 15.0 & 16.7 & 16.7 \\
\hline Ask for external help & 1.5 & 0.6 & 1.5 & 0.9 & 5.6 \\
\hline Implement actions with and for diverse families & 14.3 & 7.9 & 12.1 & 22.0 & 27.8 \\
\hline Improve school-community relationship & 2.9 & 1.7 & 2.5 & 1.8 & 7.4 \\
\hline
\end{tabular}

Source: authors' own creation.

When looking at the percentage of students of foreign origin in schools (Table 1), a noteworthy pattern is drawn: the higher the percentage of students of foreign origin at the school, the greater the number of actions to attend cultural diversity that are carried out. This relationship between actions aimed at diverse students and percentage of migrant pupils in schools is relevant for the following actions: "treating diversity as something natural," "meeting the specific needs of students with diverse backgrounds," "asking for external help," "implementing actions with and for diverse families," and "improving the school-community relationship." Specifically, schools with more than $50 \%$ of foreign students are the ones that implement these actions more frequently, and schools in which students of foreign origin account for less than $5 \%$ of the total student body are the schools that carry out these activities the least. This may be attributable to the fact that in Catalonia, schools with high levels of cultural diversity among their student populations are provided with more specific plans to attend cultural 
diversity in school through the development of the environmental education plans, learning communities, etc., projects that focus the attention on migrant students but especially on their families and the whole community. Martinez, Yanes, and Llevot (2016) highlighted the environmental education plans as a pioneering experience in Europe whose most relevant challenge is the improvement of parental involvement, focusing on migrant families. This may explain why the actions regarding the family-school and the school-community relationships increase as the number of foreign students in schools also increases. These findings are also consistent with previous studies (Forrest, Lean \& Dunn, 2016) suggesting that teachers in schools with high levels of cultural diversity among their students' populations were more proactive in implementing education policies regarding cultural diversity than schools in more homogeneous areas were.

\section{Actions addressed to all students to develop their intercultural competence and social cohesion}

Focusing on the second branch of intercultural education-actions aimed at all students-it is worth noting that the discourses of management teams encompass two kinds of response (Table 2): on the one hand, they cite how they implement these actions (how intercultural competence is approached); on the other, they mention which components of intercultural competence are developed through the strategies and pedagogical methodologies implemented (knowledge, attitudes, or skills). 
Table 2. Actions carried out by schools to improve intercultural competence in all students

\begin{tabular}{|c|c|c|c|c|c|}
\hline \multirow[b]{2}{*}{$\begin{array}{l}\text { Actions aimed at improving intercultural } \\
\text { competence in all students }\end{array}$} & \multirow[b]{2}{*}{ Total } & \multicolumn{4}{|c|}{$\begin{array}{c}\text { Percentage of students of foreign origin in } \\
\text { schools }\end{array}$} \\
\hline & & $-5 \%$ & $6-20 \%$ & $21-50 \%$ & $+50 \%$ \\
\hline \multicolumn{6}{|l|}{ How? } \\
\hline $\begin{array}{l}\text { Work on the subject in the curriculum } \\
\text { transversally }\end{array}$ & 2.6 & 3.4 & 2.5 & 2.6 & - \\
\hline $\begin{array}{l}\text { Work on the subject within the classroom, with } \\
\text { specific activities }\end{array}$ & 9.4 & 6.2 & 13.6 & 9.6 & 3.7 \\
\hline Work on the subject in school activities or projects & 9.9 & 7.3 & 12.6 & 7.9 & 13.0 \\
\hline $\begin{array}{l}\text { Work on the subject in specific subjects (religion, } \\
\text { tutorials, etc.) }\end{array}$ & 4.6 & 3.9 & 5.5 & 5.3 & 1.9 \\
\hline Use a wide variety of methodologies & 6.6 & 5.1 & 6.5 & 10.5 & 3.7 \\
\hline $\begin{array}{l}\text { Promote interchanges and interrelations between } \\
\text { diverse students }\end{array}$ & 1.9 & 1.7 & 1.0 & 3.5 & 1.9 \\
\hline \multicolumn{6}{|l|}{ What? } \\
\hline $\begin{array}{l}\text { Improve students' knowledge and understanding } \\
\text { of other cultures }\end{array}$ & 18.0 & 17.4 & 22.6 & 14.9 & 9.3 \\
\hline Improve students' skills & 9.7 & 8.4 & 10.0 & 11.4 & 9.3 \\
\hline $\begin{array}{l}\text { Improve students' attitudes of respect and } \\
\text { acceptance towards diversity }\end{array}$ & 25.5 & 21.4 & 33.7 & 18.4 & 18.4 \\
\hline
\end{tabular}

Source: authors' own creation.

Concerning how intercultural competence is developed, there are two core strategies commonly used by schools to teach the set of knowledge, skills, and attitudes that students need to live in a culturally diverse society. These strategies are "working on the subject of cultural diversity within the classroom, with specific activities (9.4\%)," such as projects, workshops, debates, or children's stories, and "working on the subject in general school activities or projects (9.9)," such as organizing intercultural celebrations or holding intercultural get-togethers and meals. By contrast, "working on the subject in the curriculum transversally," which is the most suitable and recommended way for schools to develop a truly intercultural education (Neuer, 2012), is only cited by $2.6 \%$ of respondents. Thus, a major 
conclusion that emerges from the study relates to the lack of actions taken by schools in implementing a holistic pedagogical approach of intercultural education that spreads through the principles of interculturalism in all the subjects, projects, and the school culture as a whole. Otherwise, working on the subject in general school activities or projects runs the risk of appointing immigrant pupils as ambassadors of their countries of origin by developing folkloric activities and celebrations that may lead to ethnic stereotypes or simplifications without any critical analysis (Palaiologou \& Faas, 2012; Portera, 2008). We argue, however, that these results could be explained by analyzing the educational policies in each country since there exists a lack of political will to undertake an intercultural policy of a cross-cutting nature. Focusing on Catalonia, in the official curriculum which all schools must follow, intercultural discourse is included in the language subject, and no mention is made regarding the concept of intercultural competence. However, in this regard, it should be highlighted that the most recent documents published by the Ministry of Education (published after this study was conducted) point out specific strategies and recommendations to implement holistic intercultural education. It means, then, that Catalonia is going in the right direction, albeit slowly (Garreta, Macia \& Llevot, 2020). Returning to the results of the study, and looking at what elements of intercultural education are developed in Catalan schools, there is a clear trend towards schools improving students' knowledge (18\%) and attitudes (25.5\%) towards diversity. Working with students' skills, however, is only cited by $9.7 \%$ of respondents, with social skills being the most important type of skills within this category (7.5\%). These results are somewhat consistent with Deardorff's (2006a) model for developing intercultural competence, which states that attitudes are the foundation for building intercultural competence in all students. Therefore, it is understandable that primary schools (from 6 to 12 years old) are, above all, concerned with 
developing students' attitudes towards diversity, giving rise to the idea that as children grow older and enter secondary schools, teachers are also, and first and foremost, committed to improving and deepening pupils' skills. Because, as the literature suggests (Baraldi, 2019; Council of Europe, 2014; Lourenço, 2018; UNESCO, 2013), intercultural competence encompasses a combination of attitudes, knowledge, and skills, being the three constructs that are indispensable for developing the well-known intercultural competence.

Finally, about the percentage of migrant pupils in schools, it is difficult to map out a repeated pattern concerning actions addressed to all students. Contrary to findings in other studies (Leeman \& Reid, 2006; Palaiologou \& Faas, 2012) that suggest that practice in intercultural education varies depending on the diversity of the school context, our data shows that schools with higher percentages of migrant students are not commonly the ones implementing more activities focused on fostering intercultural competence, and neither are the schools with lower levels of migration recording the lowest percentages of actions being implemented. For example, the category "working on the subject in the curriculum transversally" registers the higher rates in schools with the lowest percentages of migrant pupils. Similarly, the $3.7 \%$ of schools that account for more than $50 \%$ of foreign students work on the subject within the classroom, compared with the $13.6 \%$ of schools with between $6 \%$ and $20 \%$ of those students. These results, which are surprising given the tendency shown in previous literature in Spain (Leiva, 2017), may stand on the fact that we have broken down the actions in intercultural education into more specific groups of actions (actions aimed at culturally diverse students and actions aimed at all students), which has led to the conclusion that intercultural education depends on migrant populations for some kinds of actions, but not for others. 


\section{Deficiencies and needs of our educational system}

In the previous section, we have acknowledged a number of downsides regarding policies and practices on intercultural education in the Catalan context. However, to get a better picture of the needs and shortcomings in the implementation of intercultural education in schools, school staff were asked about the requests that they would make of a team, program, or service designed to support schools to prepare their students to live in a culturally diverse society. ${ }^{2}$

As shown in Table 3, school staff primarily called for more resources (33.2\%) and more teacher training (30.5\%). Other important suggestions were more training for the educational community as a whole (8.4\%), more actions aimed at culturally diverse students ( $5.5 \%)$, and, finally, more actions designed for both migrant and nonmigrant families (5.1\%). Regarding resources, school administrators cited, above all, the need for more human resources (25.1\%), whereas material/economic resources and more advice/general help to address the different needs of schools were remarkably minor inquiries ( $8.1 \%$ and $7.2 \%$, respectively). Further, when we closely analyzed the kind of human resources requested, we found that they asked for four different professionals. Firstly, they asked for more teachers in order to provide more specific support to their students. Secondly, they requested more external professionals, including social workers, social integrators, or specialists in intercultural education. Thirdly, they cited the request for more support at the language level: translators, interpreters, and professionals that could give them resources for achieving effective family-school communication. Finally, more intercultural mediators were also required.

\footnotetext{
${ }^{2}$ The specific question was what would you ask of a team/programme/service designed to support the schools to prepare their students to live in a culturally diverse society?
}

Campos en Ciencias Sociales

ISSN: 2339-3688 | e-ISSN: 2500-6681 | DOI: https://doi.org/10.15332/25394363

Vol. 9 N. ${ }^{0} 1$ | enero-junio de 2021 
Thus, it is clear that there is a strong demand from schools for more professionals so that they can implement an inclusive pedagogy of attention to diversity, as well as to face their migrant students' needs. It means, therefore, that human resources are not enough, although there is a diversity of professionals working in Catalan schools. Since 2004, new specific professionals providing advice and coordination regarding language and interculturality have been incorporated into the educational system. However, these external professionals, such as the pedagogical counseling teams, have to deal with many educational problems besides interculturality and migrant pupils, which suggests that their focus on intercultural education is weak and inefficient. It must also be argued, in this regard, that all the aforementioned professionals (except teachers) are not part of the school staff but are itinerant professionals who visit schools to advise teachers (less than desired). Another important reason that could explain teachers' demands is the fact that some of those external teams and professionals, such as social integrators or social educators, give support only in the so-called "schools of maximum complexity" (schools with high percentages of migrant and disadvantaged pupils). Therefore, this means that the remaining schools are left without their advice and expertise.

Table 3. Schools' requests to better prepare students to live in a culturally diverse society

\begin{tabular}{|c|c|c|c|c|c|}
\hline & \multirow[b]{2}{*}{ Total } & \multicolumn{4}{|c|}{$\begin{array}{l}\text { Percentage of students of foreign origin } \\
\text { in schools }\end{array}$} \\
\hline & & $-5 \%$ & $6-20 \%$ & $\begin{array}{l}21- \\
50 \%\end{array}$ & $+50 \%$ \\
\hline RESOURCES & 33.2 & 25.8 & 37.7 & 37.7 & 31.5 \\
\hline $\begin{array}{l}\text { Advice and general help to address the different } \\
\text { needs of schools }\end{array}$ & 7.2 & 6.2 & 9.0 & 6.1 & 5.6 \\
\hline More material and economic resources & 8.1 & 5.6 & 11.6 & 7.0 & 5.6 \\
\hline More human resources & 25.1 & 15.2 & 26.6 & 31.6 & 39.0 \\
\hline
\end{tabular}




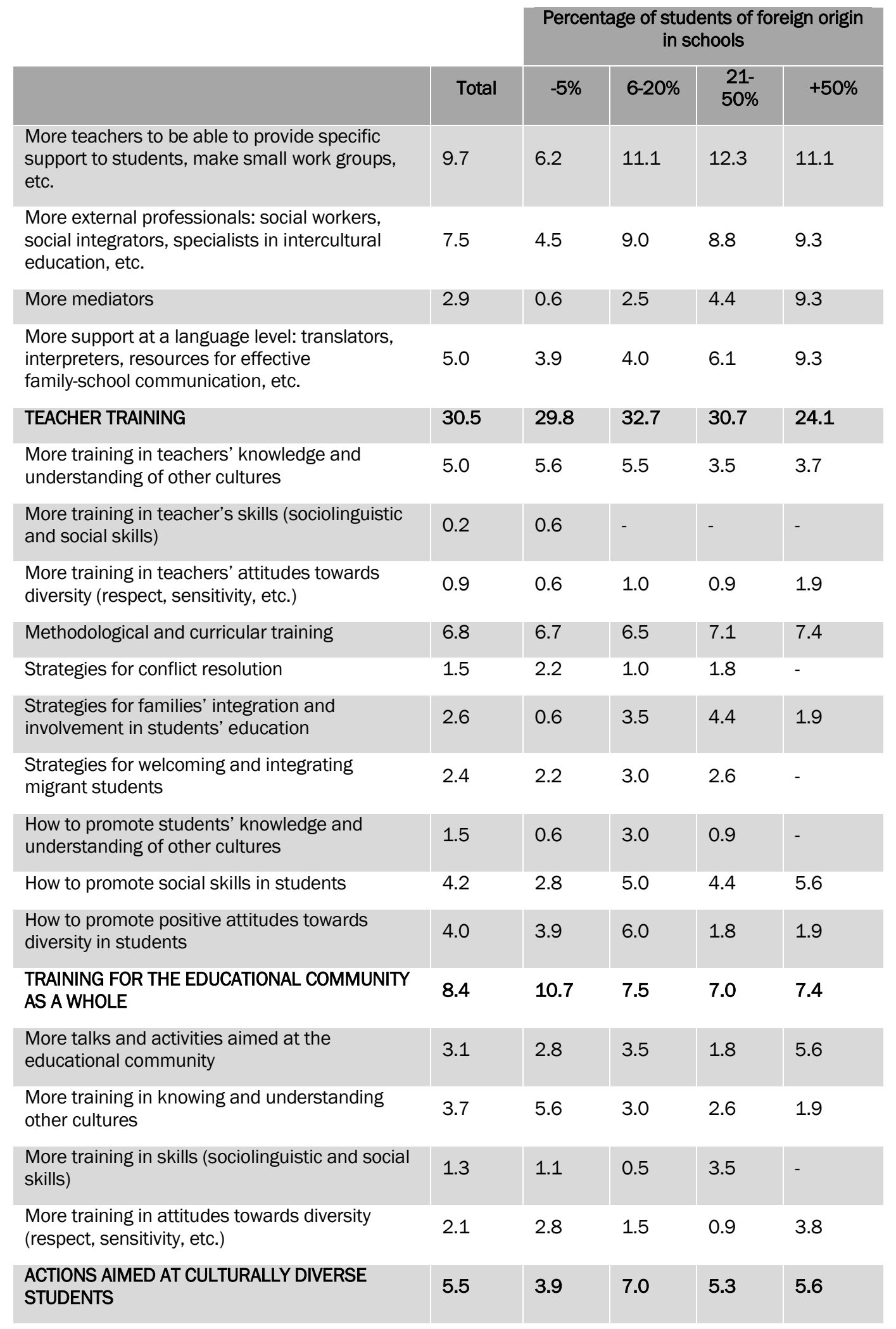

Campos en Ciencias Sociales

ISSN: 2339-3688 | e-ISSN: 2500-6681 | DOI: https://doi.org/10.15332/25394363

Vol. 9 N. ${ }^{\circ} 1$ | enero-junio de 2021 


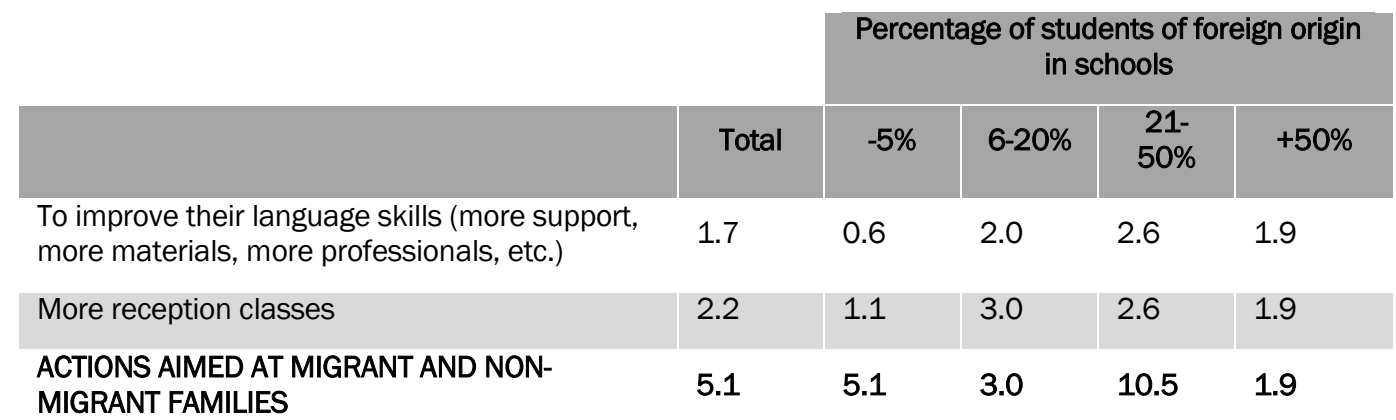

Source: authors' own creation.

The second issue that has come into focus is the requirement for more teacher training, a situation that may be due to a lack of or inefficient teacher training in this matter. The efforts to provide suitable initial and continuing teacher education in this field were rare, sporadic, and fragmentary, due amongst other things to a lack of specific legislation in the matter. Unfortunately, this situation remains quite similar after more than 20 years of intercultural policies. Today, although the political discourse includes the need to improve teaching skills in the area of cultural diversity (one of the strategies defended by the 2012-2018 Plan for Reducing School Failure in Catalonia is the professionalization of teaching), the literature has shown that, in practice, there is still a significant dearth of relevant initial (Peñalva \& Soriano, 2010) and continuing (Santos-Rego, Cernadas-Ríos \& Lorenzo-Moledo, 2014; Olmos, 2016) teacher training.

In this regard, what kind of training do schools ask for? Concerning teachers' intercultural competence, they mostly call for training in teachers' knowledge and understanding of other cultures. By contrast, the requirement for more training in teachers' skills and attitudes towards diversity is very weak. However, when we look at training to promote students' intercultural competence, the results are completely different. In this case, teachers require more training in how to teach students the necessary skills and attitudes, whereas strategies for enhancing students' knowledge and understanding of other cultures are a nonimportant request. 
Thus, it is plausible to argue that teacher training should focus on the teachers' own knowledge and understanding of different cultures, and secondly, on the acquisition of strategies for teaching students how to develop the set of skills and attitudes towards diversity that are necessary to live in our culturally diverse society. More methodological and curricular training (in general, without specifying) was also cited by a significant percentage of respondents (6.8\%).

Finally, it is important to highlight the connection trends between the percentage of migrant students in schools and the needs they would like to see covered by a specific team or service. In general, there is a statistically significant trend that shows schools with between $6 \%$ and $50 \%$ of foreign students request more resources than the schools set in the borders in terms of percentage of migrant pupils. Only schools that accounted for more than $50 \%$ of foreign students (aligned with schools between $21 \%$ and $50 \%$ of those students) reported significantly higher demands for intercultural mediators than the other schools.

\section{Conclusions}

In recent years, the discourse of promoting inclusive and intercultural education has gained increasing importance in Catalonia, especially since the publication of the recent Decree 150/2017 of educational attention of students within the framework of an inclusive system. In this context, the implementation of the "Project of coexistence" which fosters the implementation of intercultural actions in all schools and for all students must be highlighted. However, when the survey of this study was conducted (from November 2016 to February 2017), these plans and programs were not yet implemented. On the contrary, our empirical data coincided in time with the development of a general and far-reaching program to reduce school failure, which took intercultural education as an important issue but 
only within the language field. We argue, therefore, that the practices shown in this study will improve towards the path of truly intercultural education in future research, in line with the political discourse in Catalonia. Nevertheless, until now, and based on the results of our analysis, we would like to point out three recommendations or proposals for improving intercultural education in Catalan schools.

Firstly, there is the need to develop an intercultural education for all children-and all schools-that promotes intercultural competence. The study shows a great improvement in the implementation of intercultural activities to develop students' attitudes, knowledge, and skills in cultural diversity. Similarly, there is evidence to suggest that these educational actions do not vary depending on the number of foreign students in schools, as previous literature suggested (Leeman \& Reid, 2006; Leiva, 2017), which also reflects an improvement towards a truly intercultural education. However, a significant outcome is the weakness in the way that intercultural education is implemented. Ideally, intercultural education should be a holistic pedagogical approach, so the attitudes, knowledge, and skills in cultural diversity must be worked on in the curriculum transversally-and continuously, instead of working on the subject mainly within a specific classroom or school activities, as our study shows. In this regard, it would be appropriate to prepare more practical guidelines to help teachers in their planning of intercultural education, including pedagogical strategies, different methodologies, specific contents, and multiple variations of teaching materials. Secondly, the focus must be placed on improving teacher training. Initial and permanent teacher training in intercultural education is essential to improve and strengthen their intercultural competence and, therefore, their inclusive view in the context of the classroom, the school, and the educational community. Finally, it is necessary to increase schools' staffing resources. In recent years, other 
professional profiles have been added to Catalan schools, such as the Language, Interculturality, and Cohesion Teams, but in practice, their actions go beyond interculturality and migrant pupils so they have to attend many different educational problems. This is why the study shows a strong demand for more human resources in schools, including teachers as well as other specific professionals, intending to maximize the development of students and better respond to their individual needs.

\section{References}

Allemann-Ghionda, C. (2008). Intercultural education in schools: A comparative study. European Parliament. https://tinyurl.com/yylcq9g3

Banks, J. (2009). Diversity and citizenship education in multicultural nations. Multicultural education review, 1(1), 1-28. https://doi.10.1080/23770031.2009.11102861

Baraldi, C. (2019). Facilitating the Construction of Cultural Diversity in Classroom Interactions. Italian Journal of Sociology of Education, 11(1), 259-284. https://doi.10.14658/pupj-ijse-2019-1-13

Bouchard, G. (2011). What is interculturalism? McGill Law Journal, 56(2), 435-468. https://tinyurl.com/yyyps52q

Council of Europe (2014). Developing intercultural competence through education. Council of Europe Publishing. https://tinyurl.com/y5xqbva5

Deardorff, D. (2006a). Identification and assessment of intercultural competence as a student outcome of internalization. Journal of Studies in International Education, 1O(3), 241-266. https://doi.org/10.1177/1028315306287002

Departament d'Ensenyament (2018). Propostes per avançar en l'educació intercultural. Generalitat de Catalunya. https://tinyurl.com/y33qa4y9

Forrest, J., Lean, G., \& Dunn, K. (2016). Challenging racism through schools: teacher attitudes to cultural diversity and multicultural education in Sydney, Australia. Race Ethnicity and Education, 19(3), 618-638.

https://doi.10.1080/13613324.2015.1095170

Campos en Ciencias Sociales

ISSN: 2339-3688 | e-ISSN: 2500-6681 | DOI: https://doi.org/10.15332/25394363

Vol. 9 N. ${ }^{\circ} 1$ | enero-junio de 2021 
García, J.A., \& Goenechea, C. (2009). Educación intercultural. Análisis de la situación y propuestas de mejora. Wolters Kluwers.

Garreta, J. (2003). El espejismo intercultural. La escuela de Cataluña ante la diversidad cultural. Centro de Investigación y Documentación Educativa (CIDE).

Garreta, J. (2014). La interculturalidad en el sistema educativo, logros y retos. Gazeta de Antropología, 3o(2), 1-26. https://digibug.ugr.es/handle/10481/33422

Garreta, J., Macia, M., \& Llevot, N. (2020). Intercultural Education in Catalonia (Spain): Evolution of discourses and practices (2000-2016). Estudios sobre Educación, 38, 191-215. https://doi.org/10.15581/004.38.191-215

Gundara, J.S. \& Portera, A., (2008). Theoretical reflections on intercultural education. Intercultural Education, 19(6), 463-468. https://doi.org/10.1080/14675980802568244

Leeman, Y., \& Reid, C. (2006). Multi/intercultural education in Australia and the Netherlands. Compare: A Journal of Comparative and International Education, 36(1), 57-72. https://doi.org/10.1080/03057920500382325

Leiva, J. (2017). La escuela intercultural hoy: reflexiones y propuestas pedagógicas. Revista Complutense de Educación, 28(1), 29-43. https://doi.10.5209/rev_RCED.2017.v28.n1.48589

López-Roldan, P. \& Fachelli, S. (2015). Metodología de la investigación cuantitativa. Universitat Autònoma de Barcelona.

Lourenço, M. (2018). Global, international and intercultural education: three contemporary approaches to teaching and learning. On the Horizon, 26(2), 61-71. https://doi.org/10.1108/OTH-06-2018-095

Martínez, M.J., Yanes, C., \& Llevot, N. (2016). Analysis of Spanish policies for the integration of immigrant schoolchildren. Intercultural Education, 27(3), 307-319. https://doi.org/10.1080/14675986.2016.1150031

Márquez, E., \& García, M. (2014). Condiciones de posibilidad y desarrollo para una educación intercultural crítica. Tres estudios de caso en el contexto andaluz. Revista Española de Investigaciones Sociológicas, 148, 157-170. https://doi.org/10.5477/cis/reis.148.157

Campos en Ciencias Sociales ISSN: 2339-3688 | e-ISSN: 2500-6681 | DOI: https://doi.org/10.15332/25394363 Vol. 9 N. ${ }^{\circ} 1$ | enero-junio de 2021 
Mikander, P., Zilliacus, H. \& Holm, G. (2018). Intercultural education in transition: Nordic perspectives. Education Inquiry, 9(1), 40-56.

https://doi.org/10.1080/20004508.2018.1433432

Neuer, G. (2012). The dimensions of intercultural education. En J. Huber (Ed.), Intercultural competence for all (pp. 9-49). Council of Europe Publishing. https://tinyurl.com/y6gnen6w

OECD (2012). Languages in a Global World: Learning for better cultural understanding. https://doi.org/10.1787/9789264123557-en

Olmos, A. (2016). Diversidad lingüístico-cultural e interculturalismo en la escuela andaluza: Un análisis de políticas educativas. RELIEVE, 22(2), art.7. https://doi.org/10.7203/relieve.22.2.6832

Palaiologou, N., \& Faas, D. (2012). How 'intercultural' is education in Greece? Insights from policymakers and educators. Compare: A Journal of Comparative and International Education, 42(4), 563-584. https://doi.10.1080/03057925.2012.658276

Peñalva, A., \& Soriano, E. (2010). Objetivos y contenidos sobre interculturalidad en la formación inicial de educadores y educadoras. Estudios sobre Educación, 18, 37-57.

Portera, A. (2008). Intercultural education in Europe: epistemological and semantic aspects. Intercultural Education, 19(6), 481-491. https://doi.10.1080/14675980802568277

Santos Rego, M.A., Cernadas-Río, F.X., \& Lorenzo-Moledo, M.M. (2014). La inclusión educativa de la inmigración y la formación intercultural del profesorado. Revista Electrónica Interuniversitaria de Formación del Profesorado, 17(2), 123-137. https://doi.org/10.6018/reifop.17.2.196931

Santos-Rego, M.A., Cernadas-Ríos, F.X. \& Lorenzo-Moledo, M.M. (2014). La inclusión educativa de la inmigración y la formación intercultural del profesorado. Revista Electrónica Interuniversitaria de Formación del Profesorado, 17(2), 123-137. http://dx.doi.org/10.6018/reifop.17.2.196931

Santos Rego, M.A., Crespo, J., Lorenzo, M., \& Godás, A. (2012). Escuelas e inmigración en España: ¿es inevitable la segregación? Cultura y Educación, 24(2), 193-205. https://doi.10.1174/113564012804932128 
Tarocci, M. (2012). Intercultural or multicultural education in Europe and the United States. In Languages in a global world: Learning for better cultural understanding (pp. 393-406). OECD. https://doi.org/10.1787/9789264123557-28-en

UNESCO. (2013). Intercultural competences. Conceptual and operational framework. UNESCO. https://tinyurl.com/y3bzcs2e

Whitaker, T. (Ed.) (2015). Master of Arts in Teaching and Learning. Essays on Intercultural Education - From Policy to Practice. Hivernia College Dublin. https://doi.10.13140/RG.2.1.3715.4403 